\title{
Assessment of Alternative Energy Sources to Charcoal in Ntcheu District, Malawi
}

\author{
Maureen Kapute Mzuza* (iD) and Lexa Sosiwa \\ The Catholic University of Malawi, Department of Geography and Environmental Studies \\ *Corresponding author: Maureen Kapute Mzuza, maureenmzuza@yahoo.com, Cell: +265 999021884
}

Received: 17.08.2021 Accepted:11.12.2021

\begin{abstract}
Alternative sources of energy are highly recommended in most parts of the world including Malawi. The purpose of this study was to assess the alternative sources of energy to charcoal in Mphate area of Ntcheu district (central Malawi). Both qualitative and quantitative methods were used and purposive and random sampling techniques were applied in two different stages respectively. The first phase was selection of the village where residents produce and use charcoal, and the second phase was the selection of charcoal producers. Data was analysed in SPSS version 21 and MS Excel. About three quarters of forest cover has been depleted due to charcoal production. Results also revealed that only $32 \%$ of the respondents use alternative sources of energy such as briquettes (8\%), biogas $(2 \%)$, solar (1\%), electricity (20\%) and coal (1\%). In addition, $42 \%$ of the respondents produce charcoal as main source of income while $58 \%$ have other sources of income generation. The main alternative source of energy include energy produced from farm waste and biogas in addition to hydro-electricity which is expensive. It is concluded that increased charcoal production constitutes a serious setback to transitioning to alternative sources of energy. There is need to intensify afforestation programs in the area targeting the charcoal producers such as providing tree seedlings. There is also need to provide soft loans to charcoal producers to engage in other income generating activities and promoting existing small businesses to wean people from dependency on charcoal.
\end{abstract}

Keywords: Charcoal producers, Charcoal consumers, forest cover depletion, alternative energy source

\section{Introduction}

Approximately two million metric tons of fuel wood and charcoal are used up daily in the developing countries [1]. Some of the wood is transformed into charcoal while most is burnt directly. Although the energy obtained represents only about $10 \%$ of energy consumed worldwide, nearly half of the world's population solely depend on fuel wood for cooking, heating and production of marketable goods such as furniture. Technically, the world's forests are disappearing faster than being replaced. According to Turral [2], the Food and Agricultural Organization estimates that 11.3 million hectares are being lost yearly due to agriculture, grazing, commercial timbering, unrestrained burning, fuel wood consumption, and other factors with $90 \%$ of cleared land never replanted.
The demand for wood fuel is rising due to relatively high cost of hydro-electricity and petroleum based fuels (e.g. kerosene) as well as the rapid human population [3, 4, 5, 6]. For example, Brazil is the world's largest charcoal producer and consumer, and more than $90 \%$ of the population has access to electricity, yet residential consumption of wood fuel has remained at $9.7 \%$ of the country's total charcoal production [7]. Mainland China also features in the world's top 10 charcoal producers despite achieving widespread access to electricity [8]. Although Germany has a diverse portfolio of modern energy resources, is still the world's biggest importer of charcoal [9] probably for other reasons other than those used in the developing world. Likewise, in Africa, the use of charcoal is very high despite increasing availability of electricity in various countries [7]. This 
fact partly explains why large parts of Africa are reported to be in the dark, even where electricity and charcoal are used interchangeably based on preferences. In Egypt, more than $88 \%$ of the population has access to electricity, but the country rests among the world's top charcoal producers today and an active importer within the past decade [10]. Wood energy provides $70 \%$ of Kenya's population and stands as the country's main source of energy for the foreseeable future [11]. A study on the Makala Project (2009-2013) in Democratic Republic of the Congo showed that, wood energy is the primary household energy in central Africa and hence, an increase in charcoal consumption in urban centers, due to rapid population growth and a lack of alternative energy sources [12].

Studies show that around $97 \%$ of Malawian households depend on charcoal as their energy source for cooking and heating, despite various alternatives that have been introduced in the country $[14,15,16]$. The market for charcoal is thus, high in Malawi due to the increased demand resulting into deforestation, and consequently, weakening of agricultural productivity, food security and hydroelectric power generation [17, 18]. Charcoal production has caused influenced the environment with deficits resulting into climate change shocks [19].

Nowadays there are some better energy systems and techniques that can be optimized other than relying on charcoal. For example; Energy Management of Controllable Loads in Multi-Area Power Systems with Wind Power Penetration based on New Supervisor Fuzzy Nonlinear Sliding Mode Control which are employed to achieve energy management for hybrid renewable energy-based multi-area power systems (HREPSs) [20]. These Controllable Loads are considered to be cheaper solution instead of other expensive energy storage systems [20]. Some energy systems and techniques include: New design of adaptive model predictive control for energy conversion system with wind torque effect [21]; new variable structure control based on different meta and the main target of the controller design is characterized in the decreasing of the settling time and the overshoot of frequency deviations [22], use of biogas [23] and many more.
Use of biogas is considered to be cheaper source of energy in both developed and developing countries [23-28]. Biogas is produced through anaerobic digestion using feedstock sources such as livestock manure, agro-industrial residues and landfills [29]. The gas can be collected and used as fuel for cooking, lighting, and for running refrigerators and engines [3032]. Compared with other energy sources such as wind energy, biogas has more benefits [30-32]. Such benefits include ability to be stored and used on demand, Waste reduction through the use of organic agricultural waste and municipal solid waste (MSW) for energy production, improvement of the environment quality through Carbon Dioxide emission reduction and the combination of the disposal of organic waste with the formation of valuable energy "methane" by biogas [29-32].

\section{Problem Statement}

Wood energy condition in least developed countries, was exposed to decline in Africa, yet in reality consumption rests high than clean alternative sources of energy are consumed [7]. Due to increase in levels of poverty, where it is widespread that $70 \%$ earn under USD 1.90 per day and 22\% under USD 0.20 per day, the need of biomass energy sources endures to increase in Malawi which leads to unsuccessful implementation of alternative sources of energy and sustainable charcoal production [33]. Great consumption levels are coupled up with inappropriate forest management and guideline of the charcoal trade, the effect of charcoal tends to be undervalued since charcoal is not produced sustainably and low implantation of alternative Sources of energy [34].

The forests and mountains around Mphate area in Ntcheu district are bare due to high production of charcoal despite campaigns of afforestation and reafforestation. Another reason is that Ntcheu is a district that borders Mozambique and an influx of refugees in the areas accelerated depletion of the mountain forests combined with the charcoal sellers. It is imperative therefore, to assess the alternative energy sources to charcoal in the area by reviewing traditional charcoal production methods, the ecological and environmental impacts. The study aimed to (i) identify the number of households that are practicing alternative sources of 
energy, (ii) determine the possible alternative sources of energy other than charcoal and lastly, and (iii) analyze factors which significantly influence household demand for charcoal in Mphate, Ntcheu district.

\section{Conceptual Framework}

Fig. 1 summarizes the conceptual framework discussed.

INDEPENDENT VARIABLES

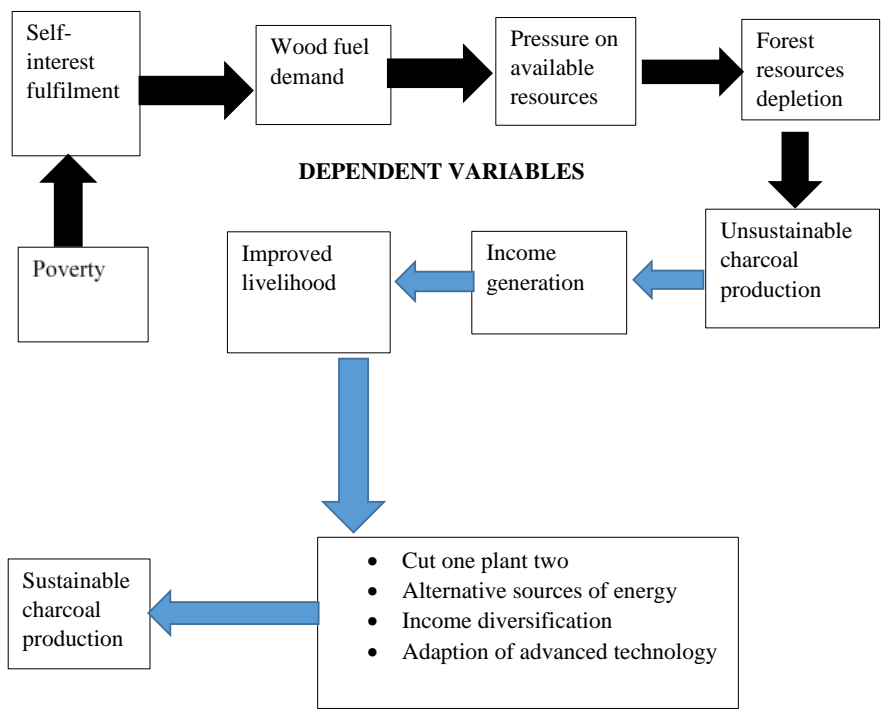

Fig. 1: Diagram showing a conceptual framework

Fig. 1 is a diagram representing the relationship of variables. In this case the conceptual framework shows how the independent variables (with black arrows) are connected to the dependent variable (with blue arrows) (Fig 1). The independent variables are the variables that are affecting the dependent variables, meaning the dependent variable existence rely on the occurrence of independent variables. The first independent variable is poverty, which is the influencing factor that leads to people relying on cheap and available resource for energy (Fig 1). The second factor is self-interest fulfillment, where people get satisfaction of needs in this case fuel for energy for cooking and heating which is causing high wood fuel demand from the environment which is causing high pressure on available resources which is severely depleted due to high demand (high population). Forest resources depletion results to unsustainable charcoal production where there is high production of charcoal to fulfil the high demand and it is leading to income generation which is resulting to improved livelihood or improved standards of living of individuals producing charcoal. On the other hand, unsustainable charcoal production has also lead to government and non-governmental organization to reinforce the rules of replacing trees after cutting them down for any personal benefits charcoal production inclusive. These restriction and rules are such as cut one tree and plant two trees, encouraging communities to use other alternative sources of energy, income diversification and adaptation of advanced technologies. The final result was establishment of woodlots, tree plantations for sustainable charcoal production.

\section{Materials and Methods}

The study was conducted in Mphate area, which is located in Ntcheu District of central Malawi (S 14 48'59.1" E $\left.034^{\circ} 38^{\prime \prime} 5.1 "\right)$. The area has a large population of charcoal users and producers despite its already dilapidated forest cover.

Primary data of the study was collected through surveys and interviews using questionnaires while secondary data were acquired from the District Commissioner's office, map coordinates, books, journal articles and reports from the internet. This study was descriptive using purposive and random sampling techniques. One village where residents consume charcoal and the other where charcoal is produced were randomly and purposively were selected respectively. The area has six villages with a population of 21,241 [35]. The whole population could not be used because it was very big instead a formula was used to find the sample size of the target age group. The study followed the formula of Stehman and Overton [36] which is represented as:

$$
n=\frac{N}{1+N(e)^{2}}
$$

Where: $\mathrm{n}=$ sample size to be studied, $\mathrm{N}=$ population size and $e=$ margin of error

A total of 60 households were therefore, interviewed and data was analyzed in SPSS and MS Excel. The researcher used content analysis techniques on the data produced by IMB SPSS version 26.0 and excel 2016. Data was coded and entered into the 
computer for analysis using SPSS (Statistical Package for the Social Sciences). Then information was interpreted using descriptive statistical to analyse the sample characteristics and variables of the study in frequency tables and graphs.

\section{Results and Discussion}

Sixty percent of the respondents were females and average age was 28 years (Fig 2). About 53\% of the respondents were married (Fig 2), where 51.7\% were households with less than 5 members.

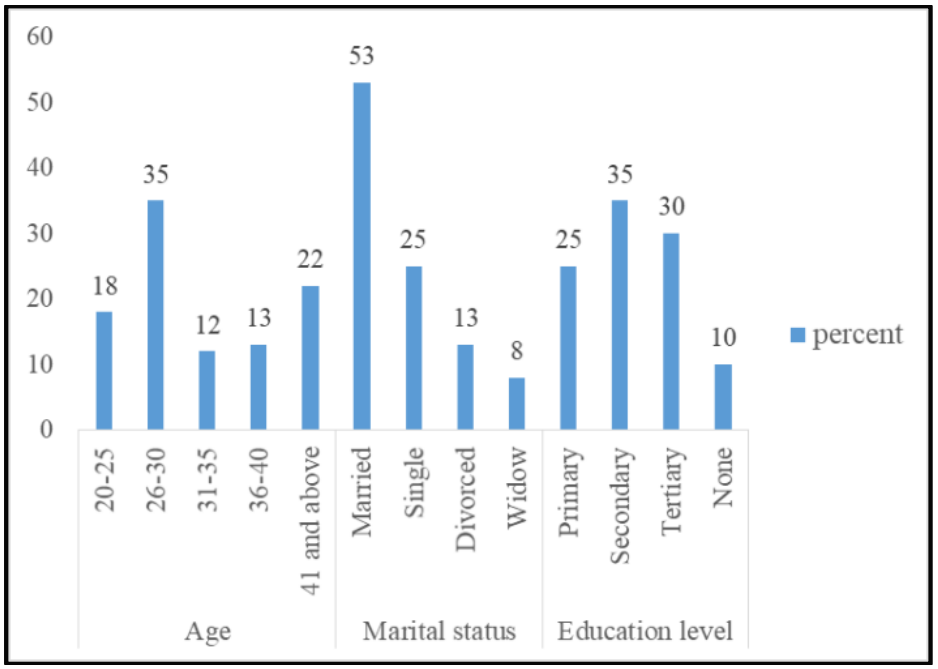

Fig. 2: Demographic information of the respondents in the area

About $25 \%, 35 \%$ and $30 \%$ of the respondents attained primary, secondary and tertiary education respectively (Fig 2) and a minimal percentage (10\%) of those that did not attend any education at all (Fig 2). On the main source of income generation, about $42 \%$ solely relied on charcoal production while the majority (58\%) had other sources of income like through farming (both crop and animal farming) (Table 1). More than half of the population $(57 \%)$ of charcoal producers harvested wood from the mountain, $28 \%$ from the forest while $12 \%$ produced charcoal using wood from farm yard and 3\% did not mention proper source (Table 1).

Most of the people sold charcoal on retail through moving around in neighborhoods (43\%), 22\% at household level, $20 \%$ at the market and $15 \%$ in different places and others supplied to other districts (Table 1). Those that practiced afforestation and re- afforestation were few (33\%) while those not practicing afforestation and re-afforestation were $67 \%$ (Table 1).

Table 1: Sources of wood for charcoal production

\begin{tabular}{|c|c|c|}
\hline Valiables & Frequency & Valid Percent \\
\hline \multicolumn{3}{|l|}{ Charcoal main source of income } \\
\hline 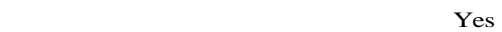 & 25 & 42 \\
\hline No & 35 & 58 \\
\hline \multicolumn{3}{|l|}{ Charcoal production per year } \\
\hline Weekly & 13 & 22 \\
\hline Monthly & 29 & 48 \\
\hline Quarterly & 11 & 18 \\
\hline All the time & 7 & 12 \\
\hline \multicolumn{3}{|l|}{ Number of bags produce per production } \\
\hline 1-10 & 15 & 25 \\
\hline $11-20$ & 14 & 23 \\
\hline $21-30$ & 21 & 35 \\
\hline $31-40$ & 10 & 17 \\
\hline \multicolumn{3}{|l|}{ Charcoal production period } \\
\hline 6 months- 12 months & 3 & 5 \\
\hline 13 months- 18 months & 12 & 20 \\
\hline 19 months - 26 months & 19 & 32 \\
\hline 27 months and above & 26 & 43 \\
\hline \multicolumn{3}{|l|}{ Availability of altenative income source } \\
\hline Yes & 39 & 65 \\
\hline No & 21 & 35 \\
\hline \multicolumn{3}{|l|}{ Wood for charcoal production } \\
\hline Forest & 17 & 28 \\
\hline Mountain & 34 & 57 \\
\hline Farm yard & 7 & 12 \\
\hline Others specify & 2 & 3 \\
\hline \multicolumn{3}{|l|}{ Charcoal selling places } \\
\hline Market & 12 & 20 \\
\hline Home & 13 & 22 \\
\hline Neighbourhood & 26 & 43 \\
\hline Other specify & 9 & 15 \\
\hline \multicolumn{3}{|l|}{ Afforestation and re-afforestation practices } \\
\hline Yes & 20 & 33 \\
\hline No & 40 & 67 \\
\hline
\end{tabular}

Findings reveal that $32 \%$ of the respondents use alternative sources of energy without solely relying on charcoal and firewood (Fig. 3) such as briquettes (8\%), biogas $(2 \%)$, solar $(1 \%)$, electricity $(20 \%)$ and coal (1\%) (Fig. 3).

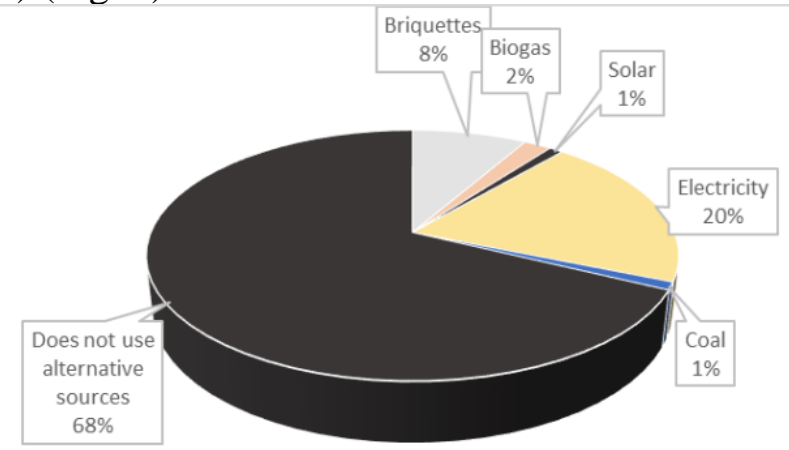

Briquettes " Biogas - Solar = Electricity - Coal - Does not use alternative sources

Fig. 3: Availability of alternative sources of energy 
The results show very low consumption of alternative sources energy in the area implying increased dependency on charcoal as the main source of energy. These results agrees with a study which was conducted in Malawi with an aim of illustrating how Malawi's change towards electrification [37]. The study used Eco health approach to energy justice. The results showed that despite introduction of other renewable resources of energy like electricity and solar energy, still the adoption of these renewable source of energy is very low [37]. Such tendency has resulted into deforestation and consequently causing reduced agricultural productivity by depleting the soil of the cycled nutrient needed in the farming system [38-39].

Almost $42 \%$ of the respondents produce charcoal as main source of income (Fig. 4) and those that have alternative sources of income $(58 \%)$ mentioned farming which is both crop and livestock farming (Fig. 4).

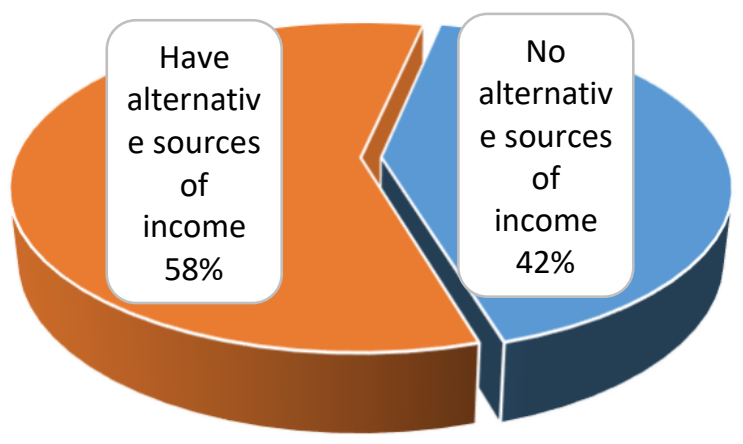

Fig. 4: Alternative sources of income other than charcoal in the area

In this case, farm wastes such as maize cobs and maize stems are source of raw materials for production of briquettes and biogas. In this technological world Kitchen and farm waste like manure can be kept in a closed and warm big jar to produce gas for cooking. The gas can also be used for electricity and may also be upgraded for other applications. In so doing reducing over dependency on biomass and increasing the levels of using alternative source of energy. Electricity is quite unaffordable to a lot of poor Malawians and thus making it unreliable to many households in the country. Use of farm waste to produce alternative sources would be ideal since the available alternative sources like briquettes are expensive for local people Malawians. For example, a bag of briquettes was sold at MK15, 000 (USD 18.75) which is an exorbitant price for rural poor people living below the poverty line on less than a dollar per day. Other studies [40] indicate farming as the dominant alternative sources of income in Kenya and saying that charcoal production was not ideal to meet needs forcing people to engage in multiple activities.

The results in this study showed that $90 \%$ of the population has never attained home-made energy source trainings (Fig 5) suggesting the reason for many continuing dependency on charcoal as the major source of livelihood. Continuing dependency on charcoal might also due to unavailability of alternative sources of energy in the area and lack of motivation in using alternative sources of energy. This was also revealed by the lowest percentage $(10 \%)$ of people that did not attain training for home-made sources of energy (Fig. 5).

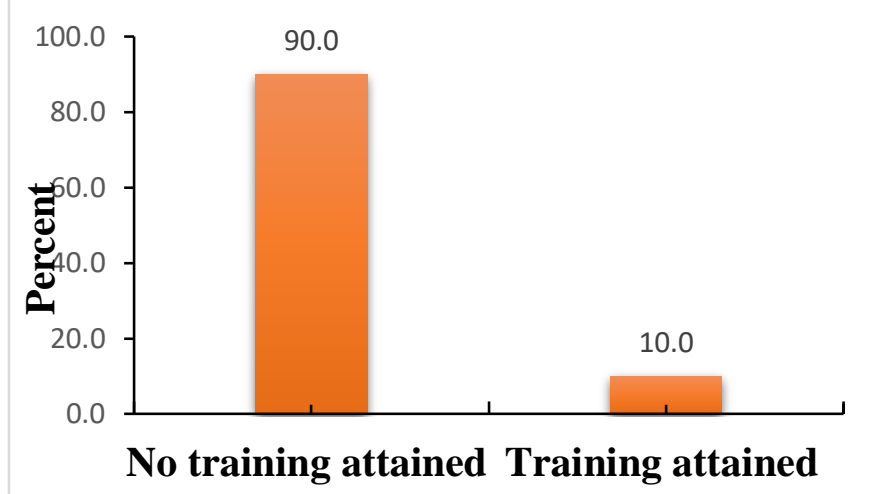

Fig. 5: Participants who did trainings in alternative energy sources

Results revealed that charcoal use has been growing in Mphate area in line with population growth hence the demand is high. Another influencing factor was low standard of living of people in the area, and affordability of charcoal and against unaffordable alternative source of energy due to high prices. Briquettes were not readily available in the area and a few households using such reported buying from Lilongwe (about $160 \mathrm{~km}$ away) becoming more expensive due to transportation costs. Less trained people in producing alternative energy sources (Fig 5) may explain the continued dependence on charcoal. Lack of training and poverty might influence people to 
continue using charcoal and firewood also reported by [41] that a majority of people abandoned charcoal for improved cooking energy sources due to improved living standards. Household would therefore, shift to alternative cooking energy like kerosene, electricity or gas if standards of living are improved. Charcoal can also be produced and used sustainably through afforestation and re-afforestation of trees and by establishing projects on production of charcoal from other than trees e.g. bamboos reported in Ghana [42]. This shows that empowerment of people through training might have an impact in enabling them to make better choices about cooking energy sources. It is not surprising therefore that a recent study (done in 2020) on market assessment for modern energy cooking services in Malawi showed that most individuals lack trainings or practice to understand alternative sources of energy for cooking [42-43]. In this study, electricity was also found to be expensive to most rural area households (71\%) opting for charcoal and firewood as main source of energy due to lower prices. The price range was MK3000 to MK 6000 (3.5 to 7 dollars) per $50 \mathrm{~kg}$ bag which is cheaper than briquettes.

Ntcheu is generally a mountainous district and forest clearing in the mountains (Fig. 4) is extensive due to high charcoal production resulting into shrubs as ground cover. Pictorial evidence of poor forest management such as afforestation is clear (Fig. 6)

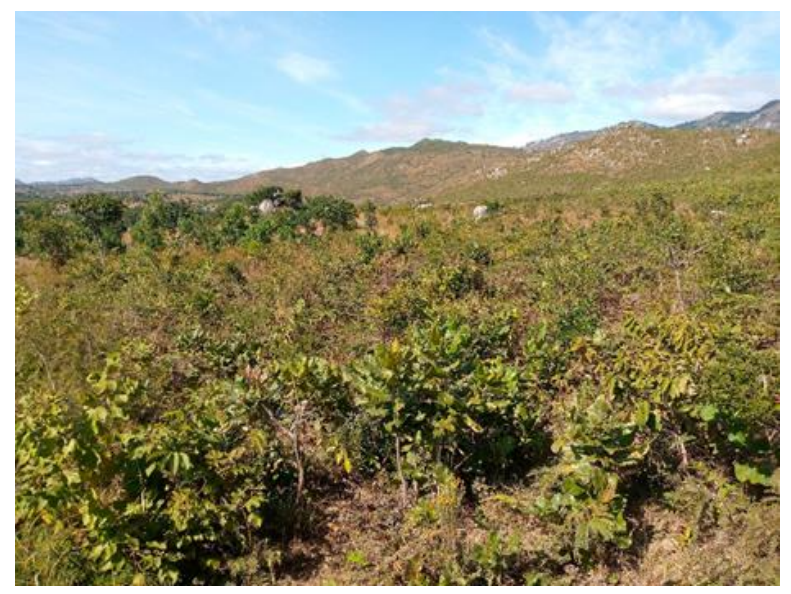

Fig. 6: Kirk Range mountains with shrubs (Source: Field photographs)
As a neighboring district with Mozambique, the area was a settlement for many refugees for many years resulting into uncontrolled destruction of the forests.

\section{Conclusion}

There is high Charcoal production and consumption and less utilization of alternative energy sources in Ntcheu resulting into extensive destruction of forest cover. Results revealed that $32 \%$ of the respondents use alternative sources of energy while $68 \%$ rely on charcoal and firewood. Some of the alternative sources of energy include briquettes, biogas, solar, electricity and coal. Unreasonable rising price of alternative sources is one of the leading factors for the charcoal demand in the area with a large population that cannot afford briquettes. Poverty, lack of training, and lack of mind-set change are some of factors leading to increased charcoal production and use in the area of study. Lucrative from charcoal has become a major driver for continued destruction of the forests resulting into adverse ecological consequences such soil erosion.

\section{Recommendations}

Briquettes and biogas would be the ideal alternative sources of energy since the materials for producing alternative sources of energy are locally available in the area, such as waste materials from the kitchen, pit latrine, dung from livestock to produce biogas. Other materials for making briquettes include dried maize stovers or maize cobs. There is need to intensify afforestation programs in the area targeting the charcoal producers such as providing tree seedlings. There is also need to provide soft loans to charcoal producers to engage in other income generating activities and promoting existing small businesses to wean people from dependency on charcoal. Capacity building of the people through trainings in making briquettes and production of biogas could also help. Reduction in the cost of electricity may also help people to shift from dependence on charcoal. There is also the need to increase wood supply through agroforestry in farming areas by introducing village, community woodlots. Charcoal can also be produced from bamboos as opposed to other trees. 
In future there is need to extend the study of alternative sources of energy to other areas of study like how training of these alternatives sources can be taught to people of Mphate area in Ntcheu and other areas. There is also need to rework on the present and past charcoal policies, forest act, the national forest policies and management since there is no rapid improvement or no improvement at all.

\section{References}

[1] R. Eba'a Atyi, J. Ngouhouo Poufoun, J. P. Mvondo Awono, A. Ngoungoure Manjeli, \& R. Sufo Kankeu, (2016). Economic and social importance of fuelwood in Cameroon. International Forestry Review, 18(1), 52-65.

[2] D. Turral, (2020). The State of the Worlds' Forests. Retrieved from https//www.fao.org.com

[3] S. Baumert, A. C. Luz, J. Fisher, F. Vollmer, C. M. Ryan, G. Patenaude, \& D. Macqueen, (2016). Charcoal supply chains from Mabalane to Maputo: Who benefits? Energy for sustainable development, 33, 129-138.

[4] R. G Sanchez, I. Kougias, M. Moner-Girona, F. Fahl \& A. Jäger-Waldau, (2021). Assessment of floating solar photovoltaics potential in existing hydropower reservoirs in Africa. Renewable Energy, 169, 687-699.

[5] M. Cotton, J. Kirshner \& D. Salite, (2021). The politics of electricity access and environmental security in Mozambique. Energy and Environmental Security in Developing Countries, 279-302.

[6] V.W. Reid, M.K. Ali, \& C.B. Field, (2020). The Future of Bioenergy. Global Change Biology, 26(1), 274-286.

[7] C. Nabukalu, \& R. Gieré, (2019). Charcoal as an energy resource: Global trade, production and socioeconomic practices observed in Uganda. Resources, 8(4), 183. Philadelphia, 240 33rd street: University of Pennsylvania. Retrieved from https//catn@sas.upenn.edu.com on 31 July $31,2021$.

[8] J.V. Dam, (2017). The Charcoal Transition: Greening the Charcoal Value Chain to Mitigate Climate Change and Improve Local Livelihoods. The charcoal transition: greening the charcoal value chain to mitigate climate change and improve local livelihoods.

[9] A. V. Balatsky, G. I. Balatsky, \& S. S. Borysov, (2015). Resource demand growth and sustainability due to increased world consumption. Sustainability, 7(3), 3430-3440.

[10] A. Oyuke, P.H. Penar, \& B. Howard (2016). Offgrid or 'off-on': Lack of access, unreliable electricity supply still plague majority of Africans.

[11] H. Zhao, B. Fei, H. Liu, H. Yang \& Z. Jiang, (2017). International Network for Bamboo and Rattan, Announcing the Genome Atlas of Bamboo and Rattan (GABR) project: promoting research in evolution and in economically and ecologically beneficial plants. GigaScience, 6(7), gix046.

[12] R. Peltier, S. Diowo, B. Marquant, M. Gigaud, A. Peroches, P. Clinquart ... \& N.J. Marien, (2012, December). Improving productivity and services of trees in slash-andburn systems. What lessons from assisted natural regeneration in DR Congo can be applied to other humid tropical regions? In The 3rd International Conference (p. 186).

[13]C. Tounsi, (2019). Beleaguered Democratic Republic of Congo Rainforest Attacked on all Sides. (5th Ed.) Physical Organisation News, xii.

[14]E. Gausi, J. S. P. Mlatho, \& C. Mikeka, (2020). A Low-Cost Tubular Biogas Digester for Rural Households in Malawi. Malawi Journal of Science and Technology, 12(1), 18-42.

[15]A. Nyambane, F.X. Johnson, C. Romeu-Dalmau, C. Ochieng, A. Gasparatos, S. Mudombi, \& G. P. Von Maltitz, (2020). Ethanol as a clean cooking alternative in Sub-Saharan Africa: Insights from sugarcane production and ethanol adoption sites in Malawi and Mozambique. In Sustainability Challenges in Sub-Saharan Africa II (pp. 115144). Springer, Singapore.

[16] C. Sumba, A. Owiny, K. Ouma, N. Matakala, C. Monde, P. W. Chirwa, \& S. Syampungani, (2021). Ecofootprint of Charcoal Production and Its Economic Contribution Towards Rural Livelihoods in Sub-Saharan Africa. In Agroecological Footprints Management for Sustainable Food System (pp. 445-472). Springer, Singapore. 
[17] V. Bachmann, \& J. D. Sidaway, (2010). African regional integration and European involvement: external agents in the East African Community. South African Geographical Journal, 92(1), 1-6.

[18] I. N. Djenontin, \& L. C. Zulu, (2021). The quest for context-relevant governance of agro-forest landscape restoration in Central Malawi: Insights from local processes. Forest Policy and Economics, 131, 102555.

[19] F. Sedano, J. A. Silva, R. Machoco, C. H. Meque, A. Sitoe, N. Ribeiro ... \& C. J. Tucker, (2016). The Impact of Charcoal Production on Forest Degradation: a case study in Tete, Mozambique. Environmental Research Letters, 11(9), 094020.

[20] M. Elsisi, N.Bazmohammadi, J. M. Guerrero, \& M. A. Ebrahim, (2021). Energy management of controllable loads in multi-area power systems with wind power penetration based on new supervisor fuzzy nonlinear sliding mode control. Energy, 221, 119867.

[21] M. Elsisi, (2019). New design of adaptive model predictive control for energy conversion system with wind torque effect. Journal of Cleaner Production, 240, 118265.

[22] M. Elsisi, (2020). New variable structure control based on different meta-heuristics algorithms for frequency regulation considering nonlinearities effects. International Transactions on Electrical Energy Systems, 30(7), e12428.

[23] A. Mishra, M. Kumar, N. S. Bolan, A. Kapley, R. Kumar, \& L. Singh, (2021). Multidimensional approaches of biogas production and upgradation: Opportunities and Challenges. Bioresource Technology, 125514.

[24]M. Gustafsson, \& S. Anderberg, (2021). Dimensions and characteristics of biogas policiesModelling the European policy landscape. Renewable and Sustainable Energy Reviews, 135, 110200.

[25] S. Bakkaloglu, D. Lowry, R. E. Fisher, J. L. France, D. Brunner, H. Chen \& G. E. Nisbet (2021). Quantification of methane emissions from UK biogas plants. Waste Management, 124, 8293.
[26]B. Stürmer, D. Leiers, V. Anspach, E. Brügging, D. Scharfy \& T. Wissel (2021). Agricultural biogas production: A regional comparison of technical parameters. Renewable Energy, 164, 171-182.

[27] A. S. Khan, T. C. D'Silva, S. Kumar, R. Chandra, V. K. Vijay \& A. Misra, (2021). Mutually trading off biochar and biogas sectors for broadening biomethane applications: A comprehensive review. Journal of Cleaner Production, 128593.

[28] M. C. Mukeshimana, Z. Y. Zhao, M. Ahmad \& M. Irfan, (2021). Analysis on barriers to biogas dissemination in Rwanda: AHP approach. Renewable Energy, 163, 1127-1137.

[29] A. Al-Rashed, \& M. Afrand, (2021). Multi-criteria exergoeconomic optimization for a combined gas turbine-supercritical $\mathrm{CO} 2$ plant with compressor intake cooling fueled by biogas from anaerobic digestion. Energy, 223, 119997.

[30] J. Lu, \& X. Gao, (2021). Biogas: Potential, challenges, and perspectives in a changing China. Biomass and Bioenergy, 150, 106127.

[31] E. S. Uhunamure, N. S. Nethengwe, \& D. Tinarwo, (2021). Development of a Comprehensive Conceptual Framework for Biogas Technology Adoption in South Africa. Resources, 10(8), 76.

[32] G. Ślusarz, B. Gołębiewska, M. Cierpiał-Wolan, J. Gołębiewski, D. Twaróg \& S. Wójcik, (2021). Regional Diversification of Potential, Production and Efficiency of Use of Biogas and Biomass in Poland. Energies, 14(3), 742.

[33] W. Coley, A. Eales, D. Frame, S. Galloway \& L. Archer (2020, November). A market assessment for modern cooking in Malawi. In 2020 IEEE Global Humanitarian Technology Conference (GHTC) (pp. 1-8). IEEE.

[34] P. Kambewa, \& L. Chiwaula, (2010). Biomass energy use in Malawi. Zomba: The University of Malawi.

[35] M. C. Chiunda, (2018). Census: Malawi Population and Housing. Zomba: National Statistical Office, Zomba: Malawi Print.

[36] S. V. Stehman, \& W. S. Overton, (2020). Spatial sampling. In Practical handbook of spatial statistics (pp. 31-63). CRC Press. 
[37] R. Grant, D. McCauley M. Von Maltzan, R. Grattage, \& E. Mwathunga, (2021). An Ecohealth approach to energy justice: Evidence from Malawi's energy transition from biomass to electrification. Energy Research \& Social Science, $75,101875$.

[38] R. Makwinja, E. Kaunda, S. Mengistou, \& T. Alamirew, (2021). Impact of land use/land cover dynamics on ecosystem service value - a case from Lake Malombe, Southern Malawi. Environmental Monitoring and Assessment, 193(8), 1-23.

[39] M. K. Mzuza, W. Zhang, F. Kapute, \& X.Wei, (2019). The Impact of Land Use and Land Cover Changes on the Nkula Dam in the Middle Shire River Catchment, Malawi. In Geospatial Analyses of Earth Observation (EO) data. IntechOpen.

[40] N. E. Mutea, (2015). Socio-economic factors influencing adoption of improved biomass energy technologies in rural and urban households in Kitui, Kenya (Doctoral dissertation, University of Nairobi).

[41] D. S. Akoto, S. T. Partey, M. Denich, M. Kwaku, C. Borgemeister, C. B. Schmitt, (2020). Environmental and financial assessment of producing bioenergy from Bambusa balcooa, Anogeissus leiocarpa and Senna siamea in Ghana. Journal of Cleaner Production, 275, 123147.

[42] X. Ma, M. Wang, D. Chen \& C. Li (2021). Energy choice in rural household cooking and heating: influencing factors and transformation patterns. Environmental Science and Pollution Research, 1-15.

[43] Z. Kapsalyamova, R. Mishra, A. Kerimray, K. Karymshakov, \& D. Azhgaliyeva, (2021). Why energy access is not enough for choosing clean cooking fuels? Evidence from the multinomial logit model. Journal of Environmental Management, 290, 112539. 